\title{
An Empirical Investigation of Oil Revenue and Economic Growth in Nigeria
}

\author{
Nweze Paul Nweze, \\ Greg Ekpung Edame,
}

Department of Economics, Faculty of Social Sciences \& Humanities, Ebonyi state Universty, Abakaliki

doi: 10.19044/esj.2016.v12n25p271 URL:http://dx.doi.org/10.19044/esj.2016.v12n25p271

\begin{abstract}
This empirical study examined oil revenue and economic growth in Nigeria between 1981 to 2014. Secondary data on gross domestic product (GDP), used as a proxy for economic growth; oil revenue (OREV), and government expenditure (GEXP) which represented the explanatory variables were sourced mainly from CBN publications. In the course of empirical investigation, various advanced econometric techniques like Augmented Dickey Fuller Unit Root Test, Johansen Cointegration Test and Error Correction Mechanism (ECM) were employed and the result reveals among others: That all the variables ware all stationary at first difference, meaning that the variables were not integrated of the same order justifying cointegration and error correction mechanism test. The cointegration result indicated that there is long run relationship among the variables with three cointegrating equation(s). The result of the error correction mechanism (ECM) test indicates that all the variables except lag of government expenditure exerted significant impact on economic growth in Nigeria. However, all the variables exhibited their expected sign in the shortrun but exhibited negative relationship with economic growth in the longrun except for government expenditure, which has positive relationship with economic growth both in the longrun and shortrun. The study concluded that Government should use the revenue generated from petroleum to invest in other domestic sectors such as Agriculture and manufacturing sector in order to expand the revenue source of the economy and further increase the revenue base of the economy.
\end{abstract}

Keywords: Oil Revenue, Government expenditure, Economic growth. JEL Classification: F43, H53, O13, O47, Q28, Q34 


\section{Introduction}

\section{Background to the Study}

Prior to the discovery of oil in Nigeria, agricultural sector was the main stay of Nigeria economy, contributing about $95 \%$ to her foreign exchange earnings, generating over $60 \%$ of her employment capacity and approximately $56 \%$ to her gross domestic earnings (World Bank, 2013). The major exportable crops were cocoa, palm products, cotton, ground nut, timber and rubber, with these products contributing most of Nigeria's export, Agriculture was the leading growth sector of the Nigerian economy while oil export was very poor. Infact, available literature on the Nigerian economy has it that Nigeria was primarily an agrarian economy, whose revenue generation was based on agriculture; statistics from the federal Bureau of statistic indicates that between 1958 and 1969, the contribution of petroleum (GDP) at current factor was just 0.007 percent. While agriculture formed the mainstay of the country's economy accounting for higher percentage of Gross Domestic Product (GDP).

Meanwhile, with the discovery of oil at Oloibiri area of Bayelsa State in 1956 by Shell BP, oil has remained a major source of energy and income in Nigeria. Although Nigeria's oil industry was founded at the beginning of the century, it was not until the end of the Nigeria civil war (1967-1970) that the oil industry began to play a prominent role in the economic life of the country.

Oil being the mainstay of the Nigerian economy plays a vital role in shaping the economic and political destiny of the country. The petroleum industry has been seen as the engine that drives the economic wheel of Nigerian economy. Its contribution can be viewed from the angle of employment generation, foreign exchange earnings, government revenue and gross domestic product.

After the discovery of oil in commercial quantity, petroleum industry in Nigeria became the largest industry. Oil provided approximately 90 percent of foreign exchange earnings and about 80 percent of Federal revenue and contributes to the growth rate of Gross domestic product (GDP) of the Nigerian economy.

The oil boom of the 1970s led to Nigeria's neglect of its strong agricultural and light manufacturing bases in favour of an unhealthy dependence on crude oil. In 2002 oil and gas exports accounted for more than $98 \%$ of export earnings and about $83 \%$ of federal government revenue. In 2011, fuel exports were 89 per cent of all merchandise exports. New oil wealth, the concurrent decline of other economic sectors, and a lurch toward a statist economic model fueled massive migration to the cities and led to increasingly widespread poverty, especially in rural areas. A collapse of basic infrastructure and social services since the early 1980s accompanied this trend. By 2002 Nigerian's per capita income had plunged to about one - quarter of 
its mid - 1970s high, below the level at independence. Along with the endemic malaise of Nigeria's non - oil sectors, the economy continues to witness massive growth of "informal sector" economic activities (Igberaese, 2013).

Nigeria being one of OPEC member countries and the second largest producer of oil in Africa was said to have high consumption of petroleum products. The high demand for petroleum products could be as a result of rising incomes (Akinlo, 2012). However, lower prices (influenced by a subsidy), a teeming population (of which Nigeria happens to be the most populous country in Africa), and various other factors that could affect demand.

From the statistics provided by the world fact book (2005; Akinlo, 2012), Nigeria is said to have an oil production of about $2.451 \mathrm{million} \mathrm{bbI} / \mathrm{day}$, while she consumes about 310,000 bbI/day(2005 EST.). As at 2006, the level of consumption increased to $312,000 \mathrm{bbI} /$ day with production level of 2.352 million bbI/day (2006 EST.). Nigeria, as at 2007 ranked $38^{\text {th }}$ position in the world with respect to oil consumption. From these facts, it is quite obvious that Nigeria, despite the decrease in oil production in 2006, still has an increase oil consumption rate.

With Nigeria's rapid growth currently becoming stagnant at around 7 per cent and oil prices which continue to be volatile, there is much discussion on the topic of what can be done to ensure continuous growth regardless of the global market. This volatility has come from international shocks caused by financial crises, strikes, wars and decreased oil production. It is because of this volatility in oil prices and Nigeria's dependence on oil that many economists raise concern about the future of the economy. As alternative fuels become more popular and oil importing countries continue to discover oil deposits, there is a need for the Nigerian economy to look to other, more manageable sources of foreign exchange and government revenue to spur economic growth (Igberaese, 2013).

Oil- exporting countries of the developing world depend heavily on oil revenue for foreign exchange earnings and for the government budget in most cases reaching 90 percent or above. The petroleum industry covers the exploration and production of crude oil as well as petroleum refining, marketing and servicing.

\section{Statement to the Problem}

Since the discovery of oil, petroleum industry has played significant role towards the development of Nigerian economy, the impacts are both positive and negative. Various scholars have advocated for the development of other sectors owing to their belief in the negative falconets of the oil industry. While others argued that the sector should be promoted and developed for its benefits. 
Nigeria is estimated to has 37.2 billion barrels of oil reserves in 2011 and produces an average of 2.13 million barrels per day (Igberaese, 2013). The hydrocarbon sector also accounts for 82 per cent of the federal government's revenue (World Bank, 2013). This suggests that Nigeria is heavily dependent on the oil sector for the majority of government spending, infrastructure and most economic development activities. With the increasing volatility of oil prices, the discovery of oil in other parts of the world and the instability of the global economy, oil imports from Nigeria to major economies such as the United States has steadily decreased. The U.S once imported $9-11 \%$ of its crude oil from Nigeria but in the first half of 2012, the share of imported oil from Nigeria to the U.S has dropped to 5\% (Igberaese, 2013).

Over dependence on oil revenue tends to distort and discourage sourcing of funds from other source by the government, for example, as a result of huge oil revenue flows; countries tend to de-emphasize income taxes as a source of government revenue. Besides, low tax ratios and high consumption expenditures (typically on imported goods) reinforce inflationary tendencies with regard to expenditure; government pay less or no attention to infrastructural development, encouragement of private sector investment, mechanizing the agricultural and manufacturing sector of the economy because of reliance on petroleum revenue.

However, it is noted that large proceeds obtain form the domestic sales and exports of petroleum products, acts like a multipliers to other sector of the economy through government expenditure; this has generated the needs to properly investigate the relationship between oil revenue and Nigeria economic growth. This study aims at achieving the following objectives:

1. Examine the long-run relationship between oil revenue and economic growth in Nigeria; and

2. Determine the extent which oil revenue impacted on the economic growth in Nigeria.

\section{Review of related literature}

\section{Theoretical Literature}

Classical theory of economic growth: The traditional classical and neoclassical growth models developed by Solow (1956) and Mincer (1958) in the late 1950's, showed that the output of an economy grows in response to larger inputs of capital and labour (all physical inputs). Non-economic variables such as human capital or human health variables have no function in these models.

This theory revealed how capitals including technology leads to increase in productivity and efficiency of workers and expand production of goods and services. In economic lexicon, this simply means that the technological progress is "exogenous" to the system. In summary the 
conventional "neoclassical" growth theory as modelled by Solow (1956) holds the view that economic growth is a result of the accumulation of physical capital and an expansion of the labour more productive.

Resource endowment theory of growth: The major advocates of this theory was Adam Smith "absolute cost advantage", David Ricardo " Comparative cost advantage" among others, they argues that countries should specialize to produce and export according to their comparative advantage. The theory of comparative advantage suggests a country gains the greatest economic benefit relative to other countries by producing at lower overall cost, commodities which a country has in abundance or can be easily produced. Other countries will therefore benefit form trade only if they accept the cost advantage of the trading country and focus on producing a commodity in which they have an advantage (Igbesere, 2013). It is this theory that guides resource endowment economist's belief in free trade, specialization and the international division of labour. This was their reasoning behind why some countries produce agricultural and mineral commodities while others produce industrial goods (O'Toole, 2007; Igbeasere, 2013).

The doctrine of comparative advantage according to the HeckscherOhlin (HO) theory states that countries produce and export the commodities which require the use of its abundant productive factors intensely (Feenstra, 2004). This model is based on the assumption of two countries, two goods and two factors and assumes that both countries have identical technologies, identical tastes, free trade in goods and different factor endowments (Feenstra, 2004). This theory was based on the proposition that countries (developed nations: Japan, Germany, United Kingdom, etc.) with an abundance of capital would export capital intensive goods and import labour intensive goods, while countries (most third world countries: African and part of Asian countries) with an abundance of labour would export labour intensive goods and import capital intensive goods (Igbeasere, 2013).

A number of empirical work has evolved to test the HO theory including Leontief (1953), he studied the U.S economy in order to prove the doctrine of comparative advantage. He utilized U.S. economy data on inputoutput accounts and U.S trade data from 1947 to evaluate the HeckscherOhlin-Samuelson (HOS) model (Igbeasere, 2013). He first measures the labour and capital used directly and indirectly in each exporting industry in order to determine the amount of labour and capital required in the production of one million dollars of U.S exports and imports (Feenstra, 2004). Leontief finds that each person employed works with $\$ 13,700$ worth of capital in producing the exports and each person employed works with $\$ 18,200$ worth of capital in producing the imports. Although the U.S was capital abundant in 1947, Leontief's findings appear to contradict the HO theory and his study 
would come to be known as the Leontief Paradox (Feenstra 2004; Igbeasere, 2013).

New Institutional Economist: This group developed as a reaction to the resource endowment economist, they argued that the resource endowment economists' assumptions of perfect information, no transaction costs, perfect competition and unbounded rationality are not always valid. These groups instead of accepting the postulation of resource endowment economist assume individuals do not have perfect information and due to their limited mental capacity create formal and informal institutions to reduce the risk of uncertainty and transaction costs. Individuals develop systems of organization to motivate agents. Therefore, the performance of the economy is dependent on the formal and informal institutions (Menard and Shirly, 2008; Igbeasere, 2013). According to NIE, transaction costs are dependent on the institutional setting; therefore, the political institutions are influential in rules, laws and contracts (Menard et al. 2008). However, both NIE and resource endowment economist accept the assumptions of competition and scarcity (Menard et al, 2008; Igbeasere, 2013).

NIE attempts to answer the question surrounding the inability of countries to foster sustainable growth and looks to the role of institutions for the answer. NIE ultimately believes that the quality of institutions will fundementedly determine the countries which experience good economic growth and the countries which do and not (Frankel 2010; Igbeasere, 2013). According to NIE, countries with high transaction costs have less trade, specialization, investment and productivity (Shirley, 2008). As Sachs and Warner (1995) points out, per capita income of resource poor countries grew three times faster between 1960 and 1990 than resource abundant countries.

\section{Empirical Literature}

The role of oil revenue to the development and well-being of many oil producing countries most especially Nigeria has remained one of the focal concern of macroeconomists and researchers for decades. A number of literatures abound on the said role of oil revenue to the economic life of the oil producing countries at large. However, there is conflicting results on the nature of the relationship between the two concepts, with some indicating reverse causality and others resulting in insignificant parameters, leading to the need for more indepth research on the subject.

Odularu (2008) examined the relationship between the crude oil sector and the Nigerian economic performance. Using the Ordinary Least Square regression method, the study revealed that crude oil consumption and export contributed to the improvement of the Nigerian economy. The study recommends that government should implement policies that would encourage the private sector to participate actively in the crude oil sector. 
On the other hand, Ibeh (2013) investigated the impact of the oil industry on the economic growth performance of Nigeria. Using ordinary least square (OLS) regression technique, she regressed Gross Domestic Product (GDP), against oil Revenue (OREV) and time appeared as repressor's. A twotailed test of $5 \%$ significant levels were conducted indicating that the two explanatory variables did not have any significant impact on growth performance of the Nigerian economy within the same period. The researcher therefore recommends that government should formulate appropriate policy mix that would motivate the firm in the oil sector to enhance improved performance and contribution of the sector. Her findings contradict the findings of Odularu (2008), who find a positive relationship between oil sector and Nigeria economic performance.

Akinlo (2012) assessed the importance of oil in the development of the Nigerian economy in a multivariate VAR model over the period 1960-2009. He model oil sector against other four sectors i.e. manufacturing, agriculture, trade \& service and building \& construction. Empirical evidence shows that the five subsectors are cointegrated and that the oil can cause other non-oil sectors to grow. However, oil had adverse effect on the manufacturing sector. Granger causality test finds bidirectional causality between oil and manufacturing, oil and building \& construction, manufacturing and building $\&$ construction, manufacturing and trade \& services, and agriculture and building \& construction. It also confirms unidirectional causality from manufacturing to agriculture and trade \& services to oil. No causality was found between agriculture and oil, likewise between trade \& services and building \& construction. The paper recommends appropriate regulatory and pricing reforms in the oil sector to integrate it into the economy and reverse the negative impact of oil on the manufacturing sub sector.

The findings of Ibeh and Akinlo revealed that petroleum industry have not rely contributed significantly to Nigeria economy this owned to the fact that Nigeria government have not used her revenue generated from the sector efficiently. The industry has faced enormous challenges such as lack of infrastructures, lack of proper turn around maintenance in the oil and gas industries, high rate of corruption, militant insurgences, the recent Boko haram, bunkering, and all sorts of criminal activities.

Nwezeaku (2010) point that, the economy has been bedeviled by perennial underdevelopment, poverty, increasing debt burden due to multiple problems such as poor energy supply and power outages, systematic collapsing of industries and infrastructures, lack of proper turn around maintenance in the oil and gas industries, high are of corruption, militant insurgences, criminal activities etc. The is really faced with poor human developmental and economic indices as evidenced by high rate of perennial and persistent inflation, low per capital income, poor income distribution, 
GDP and sustained impoverishment, mismanagement of abundant natural, human and material resources, insatiability greed and loss for excessive wealth. Corruption practices at all levels and political banditry have been the bane of the Nigeria economy.

Shihab (2001) have linked abundant natural resources to show economic collapse, civil conflict and socio-economic collapse. They further state that, all natural resources, oil has been found to have the highest risk of civil conflict because of the large rents it offers. Therefore Nigeria needs to be careful about the way it manages her petroleum to avoid socio-economic collapse.

Ibaba (2005) posits that the Nigeria economy has been facing developmental crisis such as high level of poverty, declining economic growth, collapse of local economics and social infrastructure. There have been corruption, financial indiscipline, lack of proper accountability of oil revenue, co-existence of abundant foreign reserves have become the order of the day (Shihab, 2001; Ibeh, 2013).

The works of Nwezeaku (2010), Shihab (2001) and Ibaba (2005) provided evidence to contradict the facts that abundance of natural resources do not really spur economic growth but rather leads to several ethnic crisis and civil unrest. At the same vein Sachs and Warner (1997) provide empirical evidence to explain the slow growth in Sub Saharan Africa from 1965-1990. They hypothesize that factors such as geography, economic policy, demography and initial conditions all explain the growth in Africa in recent decades (Sachs and Warner, 1997). Therefore they run regressions using a variety of variables as determinants of growth and estimate a variety of factors which were shown to influence growth in Africa. Natural resource endowments were found to correlate with slower growth as the work from Sachs and Warner (1995) also showed. The regression showed that as natural resource exports increased GDP by .1, growth was projected to decrease by .33 percentage points annually (Sachs and Warner, 1997).

\section{Methodology}

\section{Model Specification}

Following the research work of Akinlo (2012) in assessing the importance of oil in the development of the Nigerian economy in a multivariate VAR model over the period 1960-2009. The adapted form of the model is expressed in a multiple regression and modified with the incorporation of exogenous factors considered includes: oil revenue (OREV), government expenditure (GEXP). Government expenditure was incorporated in the model because revenue from oil export constitutes 82 percent of government revenue which form their expenditure (World Bank, 2013). 
The dynamic form of the modified adapted multiple regression model (1) is considered by incorporating first autoregressive i.e $\left[\mathrm{AR}(1)=\Delta \mathrm{GDP}_{\mathrm{t}-1}\right]$ as one of the explanatory variables. Therefore the functional form of the model is expressed below;
$\mathrm{GDP}_{\mathrm{t}}$
$=$
$\mathrm{F}\left(\mathrm{GDP}_{\mathrm{t}-1,}\right.$,
$\mathrm{OREV}_{\mathrm{t}}$,
GEXP

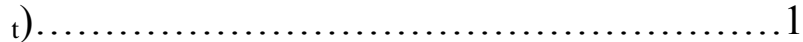

The mathematical and econometric form of the model is as given below; $\Delta \mathrm{GDP}_{\mathrm{t}}=\delta_{0}+\delta_{1} \Delta \mathrm{GDP}_{\mathrm{t}-1}+\delta_{2} \Delta \mathrm{OREV}_{\mathrm{t}}+\delta_{3} \Delta \mathrm{GEXP}_{\mathrm{t}}+$

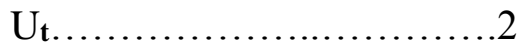

Where;

$\delta_{0}=$ constant term/parameter intercept

$\delta_{1}, \delta_{2}$, and $\delta_{3},=$ coefficients of the parameters estimates.

$\mathrm{U}_{\mathbf{t}}=$ Error Term

$\delta_{1}, \delta_{2}$, and $\delta_{3},>0$

\section{Evaluation procedure}

The properties of the time series were examined using the Augmented Dickey-Fuller (ADF) unit root tests to determine their long-run convergence and stationary levels, also was error correction mechanism was used to estimate the short run speed of adjustment from this equilibrium.

\section{Data Source}

The time series data on real gross domestic product, trade openness, foreign direct investment, external debt, and exchange rate were sourced from the Central Bank of Nigeria (CBN) Statistical Bulletin various issues and the World bank publications.

\section{Result and discussion}

\section{Unit Root Test Results}

To properly examine the trend relationship and the nature of stationarity in this study, the researcher adopted the Augmented Dicks-Fuller test (ADF) at trend only in order to eliminate the possibility of obtaining spurious result. Thus, below is the tabular representation of the empirical results.

Table1: Augmented Dickey Fuller Unit Root Test Trend and Intercept

\begin{tabular}{|c|c|c|c|c|c|c|}
\hline Variables & Level & $\begin{array}{c}1^{\text {st }} \\
\text { difference }\end{array}$ & $\begin{array}{c}2^{\mathrm{ND}} \\
\text { Difference }\end{array}$ & $\begin{array}{l}\text { Critical } \\
\text { value } \\
(5 \%)\end{array}$ & $\begin{array}{l}\text { Order of } \\
\text { integration }\end{array}$ & Remark \\
\hline $\mathrm{D}(\mathrm{GDP})$ & $\begin{array}{c}- \\
2.128327 \\
\end{array}$ & $\begin{array}{c}- \\
5.279981\end{array}$ & - & $\begin{array}{c}- \\
3.557759\end{array}$ & $\mathrm{I}(1)$ & Stationary \\
\hline $\mathrm{D}(\mathrm{OREV})$ & $\begin{array}{c}- \\
1.622279 \\
\end{array}$ & $\begin{array}{c}- \\
6.416124 \\
\end{array}$ & - & $\begin{array}{c}- \\
3.568379 \\
\end{array}$ & $\mathrm{I}(1)$ & Stationary \\
\hline
\end{tabular}




\begin{tabular}{|c|c|c|c|c|c|c|}
\hline $\mathrm{D}($ GEXP) & - & - & - & $\mathrm{I}(1)$ & Stationary \\
& 1.017561 & 8.414963 & & 3.574244 & & \\
\hline
\end{tabular}

Source: Researchers Computation December, 2016 (See Appendix)

From table 1 above none of the variables ware stationary at level since their critical value is less than 5\% level of significance, but after differencing the variables by one all became stationary. This means that all the variables were stationary at first difference since their critical value is greater than $5 \%$ level of significance i.e. (-5.279981, -6.416124, and -8.414963>-3.568379)

Hence, since all the variables are not stationary at level and are not integrated at level, co-integration analysis is justified. We there proceed to conduct the long run relationship of the variables and their short term speed of adjustment to equilibrium.

\section{Cointegration Test}

The result of the test is summarized below:

\section{TABLE 2}

Series: GDP OREV GEXP

Unrestricted Cointegration Rank Test (Trace)

\begin{tabular}{ccccc}
\hline \hline $\begin{array}{c}\text { Hypothesized } \\
\text { No. of CE(s) }\end{array}$ & Eigenvalue & $\begin{array}{c}\text { Trace } \\
\text { Statistic }\end{array}$ & $\begin{array}{c}0.05 \\
\text { Critical Value }\end{array}$ & Prob. ${ }^{* *}$ \\
\hline \hline None $*$ & 0.867230 & 101.9105 & 29.79707 & 0.0000 \\
At most $1 *$ & 0.551708 & 37.29816 & 15.49471 & 0.0000 \\
At most $2 *$ & 0.304592 & 11.62422 & 3.841466 & 0.0007 \\
\hline \hline
\end{tabular}

Trace test indicates 3 cointegrating eqn(s) at the 0.05 level

* denotes rejection of the hypothesis at the 0.05 level

**MacKinnon-Haug-Michelis (1999) p-values

Source: Researchers Computation December, 2016 (See Appendix)

This test is used to test for the long run relationship between the variables under consideration; it was carried out using the augmented eagle Granger test on the residuals under the following hypothesis:

$\mathrm{H}_{0:} \delta=0$ (Not- cointegrated)

$\mathrm{H}_{1}: \delta \neq 0$ (cointegrated)

Decision Rule: Reject $\mathrm{H}_{0}$ if T*. Adf (trace Statistic) > T-Adf (Critical Value), Accept if otherwise.

From table 2 above it can be seen that the trace statistic $\left(\mathrm{t}^{*}\right)$ is greater than the T-adf i.e. the critical value at $5 \%$ or since the Eigen value are greater than 5\% level of significance, we reject $\mathrm{H}_{\mathrm{o}}$ and conclude that the variable are cointegrated. Put differently, there is a sustainable long-run relationship (i.e. steady-state path) between gross domestic product (GDP), Oil revenue (OREV), and Government expenditure (GEXP). The normalized co- 
integrating coefficients for one co-integrating equation given by the long-run relationship is

$$
\mathrm{GDP}=3734.527+1.7184810 \mathrm{REV}-16.69059 \mathrm{GEXP}
$$

Where GDP is the dependent variable, 1.718481 is the coefficient of Oil revenue (OREV), and -16.69059 is the coefficient of government expenditure (GEXP).

The positive sign of oil revenue indicate a direct relationship between both variables. This implies that revenue generated from oil sales has potential significant impact on Nigeria economic growth through government expenditure in the long run. Although, there was an inverse relationship between OREV and GDP in the short run. This might be as a result of the fact that the policy maker has so relied on oil revenue to the detriment of other promising sector especially the agriculture sector, which if not corrected may have serious effect on the economic growth of Nigeria in the long run.

\section{Error Correction Mechanism}

The existence of a long-run co-integrating equilibrium provides for short-term fluctuations. In order to strengthen out or absolve these fluctuations, an attempt was made to apply the Vector Error Correction Mechanism (ECM). As noted, the VECM is meant to tie the short-run dynamics of the co-integrating equations to their long-run static dispositions. Table 3 below shows the error correction mechanism result.

Table 3: Vector Error Correction Mechanism Result Sample (adjusted): 19832012 Included observations: 28 after adjustments

\begin{tabular}{|c|c|c|c|c|c|}
\hline Variable & Coefficient & Std. Error & t-Statistic & Prob. & Remarks \\
\hline $\mathrm{C}$ & 1532.814 & 707.623 & 2.16615 & 0.0338 & $\overline{\text { Reject }}$ \\
\hline $\mathrm{D}(\mathrm{GDP}(-1))$ & 0.585738 & 0.12777 & 4.58415 & 0.0000 & Reject \\
\hline $\mathrm{D}(\operatorname{OREV}(-1))$ & -3.131149 & 0.43105 & -7.26396 & 0.0000 & Reject \\
\hline $\mathrm{D}(\operatorname{GEXP}(-1))$ & -5.324755 & 3.73886 & -1.42417 & 0.1589 & Accept \\
\hline $\operatorname{ECM}(-1)$ & -0.519923 & 0.13632 & -3.81406 & 0.0003 & Reject \\
\hline
\end{tabular}

From the result the coefficient of error correction term is -0.5199 . This showed that $51.99 \%$ of the errors in the short run are corrected each year. Thus, the coefficient captures the speed for adjustment at which the short-run of GDP ties with its long-run. The result is significant since the coefficient of multiple (0.8946) determination is greater than zero and the error correction variable (ECM), is negative which shows that there is a feedback from the previous year's disequilibrium.

A mere observation of the individual parameters reveals that all the variables ware significant since their $p$-value is greater than $5 \%$ level of 
significance, except government expenditure which was not significant given the $5 \%$ level of significance and its P-value. The a priori expectation of the oil revenue is expected to be positive, which mean that the higher the level of revenue generated from oil the higher the economic growth. The regression result showed that the coefficient is negative, even though it has a positive relationship with economic growth in the long-run as revealed by the VECM result. This variable is expected to have positive relationship with economic growth both in the short run and in the long-run. The positive relationship between the two variables signifies that revenue generated from oil has form the major source of revenue of Nigeria government since its discovery in commercial quantity at Oloibiri area of Bayelsa state.

Since its discovery, the sector has contributed to over $80 \%$ of government revenue in Nigeria; the flux of revenue from the sector has led to the neglect of other sectors especially the agricultural sector, which is why the short term result reveals a negative relationship between oil revenue and economic growth at large. The Oil mining and export on the other hand is positively related to economic growth. The discovery oil in large quantity has increase the flow of FDI in the country, either through purchase or the establishment of new production facilities (i.e. green field" investment), the flow of FDI contribute to capital formation and to export earnings, contribution to technological change and growth of the economy.

The result revealed that the government expenditure has negative with economic growth in both the short and long run. The sign of government expenditure is expected to be positive for economic growth to take place. This has to do mainly with the state and expenditure pattern of government. The expenditure of government through accelerator principle is supposed to spur every other sector of the economy. As postulated by Keynes, if an economy is experiencing recession government can through her expenditure boost the economy; by increasing her expenditure thereby raising the aggregate demand of the economy depending on the multiplier. In Nigeria oil revenue constitute $80 \%$ of government revenue which they intern expend to drive the economy, if government spend in without adhering to certain guiding principles such as principle of sanction, principle of economy among others it can lead to negative relationship between government spending and economic growth in both short and long-run.

\section{Summary, conclussion and recomendation}

The paper investigated the relationship between oil revenue and economic growth in Nigeria between 1981 and 2014. Error Correction Mechanism was used to estimate the regression result. Cointegration test and Unit root test was also conducted to determine the stationarity and long-run relationship between the variables. The results showed that oil revenue has 
positive relationship in the long-run but has a negative relationship with economic growth in the short-run. The implication is that revenue generated from oil is yet to be used effectively and efficiently in Nigeria. Embezzlement of funds and reckless spending of revenue generated from oil has remains one of the major problem of Nigeria economy. Nigeria needs to improve on her trade with the rest of the world, the revenue generated from oil should be used judiciously to develop other sector of the economy most especially the agricultural sector and the manufacturing sector at large.

Also sound macroeconomic policies are needed to reinforce the growth exercise for a better result in the country. The positive sign is an indicator that Nigeria at large is benefitting from oil revenue; this could be a product of the oil export in Nigeria which makes Nigeria to enjoy a favourable balance of payment. This outcome is expected, oil export encourage or leads to favourable balance of payment which boost the currency and image of the country in the international scene. This is needed to attract foreign direct investment which is essential for all developing countries and Nigeria is no exception. Sequel to the finding of this research work, it has been established that with the present situation and policies adopted to stabilize the economy in Nigeria, the country stands a good chance of benefiting from oil revenue. Government should use the revenue generated from petroleum to invest in other domestic sector such as Agriculture and manufacturing sector in order to expand the revenue source of the economy and also increase the revenue. The Nigerian government should invest oil revenue more on the economic sectors that has significant and direct bearing on the economy in order to improve the value of gross domestic product. Government should give training on quality systems, technology development and directly acquire foreign technology for use by local firms. Government should focus not only on petroleum revenue generation but should also re-direct its attention to proper management of the revenue and effective control of necessary expenditure.

\section{References:}

Akinlo, A. E (2012). How important is oil in Nigeria's economic growth? Journal of Sustainable Development, 5(4).

Central Bank of Nigeria (2006). Central bank of Nigeria annual report. Abuja, Nigeria: Central Bank of Nigeria.

Central Bank of Nigeria (2007). Central bank of Nigeria annual report. Abuja, Nigeria: Central Bank of Nigeria.

Central Bank of Nigeria (2008). Central bank of Nigeria annual report. Abuja, Nigeria: Central Bank of Nigeria.

Central Bank of Nigeria (2010). Central bank of Nigeria annual report. Abuja, Nigeria: Central Bank of Nigeria. 
Feenstra, R. C. (2004). "The Heckscher-ohlin model". Advanced international trade: Theory and Evidence. Princeton: Princeton University Press. pp. 3163

Frankel, J.A (2010). The natural resource curse: a survey. National Bureau of Economic Research. Working paper No.15836.

Ibaba, S. T. (2005). Political foundations of the resource curse. Journal of Development Economics, 79(2), 447-468.

Igbeasere, T. (2013). The Effect of Oil Dependency on Nigeria's Economic Growth. Journal of International Institute of Social Science, 3(1)

Leontief, W (1953). Studies in the structure of the American economy. New York: Oxford University Press.

Menard, C and M.M Shirley (2008). Institutions and development, in C. Menard and M.M. Shirley (eds) Handbook of New Institutional Economics, 1-18.

Mincer, J. (1958). Investment in human capital and personal income distribution. Journal of Political Economy, 66(4); 281

Ibeh, D. S. (2013). Diversification and development of the UAE's economy: Messina, Italy: University of Messina.

Nwezeaku, O. (2010). Why policies fail in Nigeria: An evaluation of agriculture policies made from 1972-1985. OIDA International Journal of Sustainable Development, 1(1), 84-86.

Odularu, G. O. (2008). Crude oil and the Nigerian economic performance. World Trade Organisation (WTO), Centre William Rappard, Rue de Lausanne, 3(4).

O’Toole, G. (2007). Politics Latin America. Harlow: Pearson Education Limited.

Sachs, J.D, Warner, A. and M Warner (1995). Natural resource abundance and economic growth. National Bureau of Economic Research, Working Paper No.5398.

Sachs, J.D. and A. Warner (1997). Sources of slow growth in African Economies. Development Discussion Paper No. 545, Harvard Institute of International Development, July 1996.

Shihab, M. (2001). Economic Development in the UAE, in I. Al Abed and P. Hellyer (eds) United Arab Emirates: A New Perspective, 249-259.

Shirley, M. (2008). Institutions and Development, in C. Menard and M.M. Shirley (eds) Handbook of New Institutional Economics, 611-638.

Solow, R. M. (1956). A contribution to the theory of economics growth. Quarterly Journal of Economics (Oxford Journals), 70 (1), 65-94

World Bank (2013). Nigeria economic report (No. 1). Washington, DC: World Bank. World Bank (1994) Indonesia: Sustaining Development. Washington, DC: World Bank. 


\section{APPENDIX I}

\section{DATA FOR REGRESSION}

\begin{tabular}{|c|c|c|c|}
\hline YEARS & $\begin{array}{c}\text { GDP } \\
\text { ( }{ }^{*} \text { 'Billions) }\end{array}$ & $\begin{array}{c}\text { OREV } \\
\text { ( }{ }^{\text {'Billions) }}\end{array}$ & $\begin{array}{c}\text { GEXP } \\
\text { (\# 'Billions) }\end{array}$ \\
\hline 1981 & $94.3300 \backslash$ & 8.560000 & 11.41000 \\
\hline 1982 & 101.0100 & 7.810000 & 9.640000 \\
\hline 1983 & 110.0600 & 7.250000 & 11.92000 \\
\hline 1984 & 116.2700 & 8.270000 & 9.930000 \\
\hline 1985 & 134.5900 & 10.92000 & 13.04000 \\
\hline 1986 & 134.6000 & 8.110000 & 16.22000 \\
\hline 1987 & 193.1300 & 19.03000 & 22.02000 \\
\hline 1988 & 263.2900 & 19.83000 & 27.75000 \\
\hline 1989 & 382.2600 & 39.13000 & 41.03000 \\
\hline 1990 & 472.6500 & 71.89000 & 60.27000 \\
\hline 1991 & 545.6700 & 82.67000 & 66.58000 \\
\hline 1992 & 875.3400 & 164.0800 & 92.80000 \\
\hline 1993 & 1089.680 & 162.1000 & 191.2300 \\
\hline 1994 & 1399.700 & 160.1900 & 160.8900 \\
\hline 1995 & 2907.360 & 324.5500 & 248.7700 \\
\hline 1996 & 4032.300 & 408.7800 & 337.2200 \\
\hline 1997 & 4189.250 & 416.8100 & 428.2200 \\
\hline 1998 & 3989.450 & 324.3100 & 487.1100 \\
\hline 1999 & 4679.210 & 724.4200 & 947.6900 \\
\hline 2000 & 6713.570 & 1591.680 & 701.0600 \\
\hline 2001 & 6895.200 & 1707.560 & 1018.030 \\
\hline 2002 & 7795.760 & 1230.850 & 1018.160 \\
\hline 2003 & 9913.520 & 2074.280 & 1225.970 \\
\hline 2004 & 11411.07 & 3354.800 & 1426.200 \\
\hline 2005 & 14610.88 & 4762.400 & 1822.100 \\
\hline 2006 & 18564.59 & 5287.570 & 1938.000 \\
\hline 2007 & 20657.32 & 4462.910 & 2450.900 \\
\hline 2008 & 24296.33 & 6530.630 & 3240.820 \\
\hline 2009 & 24794.24 & 3191.940 & 3452.990 \\
\hline 2010 & 54612.26 & 5396.090 & 4194.580 \\
\hline 2011 & 62980.40 & 8878.970 & 4712.060 \\
\hline 2012 & 71713.94 & 8025.970 & 4605.390 \\
\hline 2013 & 80092.56 & 6809.230 & 5185.320 \\
\hline 2014 & 89043.62 & 6793.720 & 4578.060 \\
\hline
\end{tabular}

SOURCE: CENTRAL BANK OF NIGERIA (CBN) STATISTICAL BULLETINE, 2014 


\section{APPENDIX II \\ REGRESSION RESULT \\ UNIT ROOT RESULT (@ LEVEL)}

Null Hypothesis: LOG(GDP) has a unit root

Exogenous: Constant, Linear Trend

Lag Length: 0 (Fixed)

\begin{tabular}{cccc}
\hline \hline & t-Statistic & Prob. $^{*}$ \\
\hline \hline \multicolumn{2}{c}{ Augmented Dickey-Fuller test statistic } & -2.128327 & 0.5118 \\
\hline Test critical values: & 1\% level & -4.262735 & \\
& 5\% level & -3.552973 & \\
& 10\% level & -3.209642 & \\
\hline \hline
\end{tabular}

*MacKinnon (1996) one-sided p-values.

Augmented Dickey-Fuller Test Equation

Dependent Variable: D(LOG(GDP))

Method: Least Squares

Date: 12/26/15 Time: 18:23

Sample (adjusted): 19822014

Included observations: 33 after adjustments

\begin{tabular}{ccccc}
\hline \hline Variable & Coefficient & Std. Error & t-Statistic & Prob. \\
\hline \hline LOG(GDP(-1)) & -0.258735 & 0.121568 & -2.128327 & 0.0416 \\
C & 1.248124 & 0.494267 & 2.525201 & 0.0171 \\
@ TREND(1981) & 0.058333 & 0.027534 & 2.118598 & 0.0425 \\
\hline \hline R-squared & 0.131237 & Mean dependent var & 0.207578 \\
Adjusted R-squared & 0.073320 & S.D. dependent var & 0.186637 \\
S.E. of regression & 0.179665 & Akaike info criterion & -0.508939 \\
Sum squared resid & 0.968384 & Schwarz criterion & -0.372892 \\
Log likelihood & 11.39749 & Hannan-Quinn criter. & -0.463163 \\
F-statistic & 2.265938 & Durbin-Watson stat & 1.719175 \\
Prob(F-statistic) & 0.121204 & & \\
\hline \hline
\end{tabular}


Null Hypothesis: LOG(OREV) has a unit root

Exogenous: Constant, Linear Trend

Lag Length: 0 (Fixed)

\begin{tabular}{|c|c|c|c|}
\hline & & t-Statistic & Prob.* \\
\hline \multicolumn{2}{|c|}{ Augmented Dickey-Fuller test statistic } & -1.622279 & 0.7622 \\
\hline \multirow[t]{3}{*}{ Test critical values: } & $1 \%$ level & -4.262735 & \\
\hline & $5 \%$ level & -3.552973 & \\
\hline & $10 \%$ level & -3.209642 & \\
\hline
\end{tabular}

*MacKinnon (1996) one-sided p-values.

Augmented Dickey-Fuller Test Equation

Dependent Variable: D(LOG(OREV))

Method: Least Squares

Date: 12/26/15 Time: 18:25

Sample (adjusted): 19822014

Included observations: 33 after adjustments

\begin{tabular}{ccccc}
\hline \hline Variable & Coefficient & Std. Error & t-Statistic & Prob. \\
\hline \hline LOG(OREV(-1)) & -0.226375 & 0.139541 & -1.622279 & 0.1152 \\
C & 0.631576 & 0.253499 & 2.491429 & 0.0185 \\
@ TREND(1981) & 0.052232 & 0.035829 & 1.457815 & 0.1553 \\
\hline \hline R-squared & 0.093877 & Mean dependent var & 0.202323 \\
Adjusted R-squared & 0.033469 & S.D. dependent var & 0.386252 \\
S.E. of regression & 0.379734 & Akaike info criterion & 0.987816 \\
Sum squared resid & 4.325933 & Schwarz criterion & 1.123862 \\
Log likelihood & -13.29896 & Hannan-Quinn criter. & 1.033591 \\
F-statistic & 1.554039 & Durbin-Watson stat & 1.975874 \\
Prob(F-statistic) & 0.227934 & & \\
\hline \hline
\end{tabular}

Null Hypothesis: LOG(GEXP) has a unit root

Exogenous: Constant, Linear Trend

Lag Length: 0 (Fixed)

\begin{tabular}{cccc}
\hline \hline & & t-Statistic & Prob. $^{*}$ \\
\hline \hline \multicolumn{2}{c}{ Augmented Dickey-Fuller test statistic } & -1.017561 & 0.9277 \\
\hline Test critical values: & 1\% level & -4.262735 & \\
& $5 \%$ level & -3.552973 & \\
& $10 \%$ level & -3.209642 & \\
\hline \hline
\end{tabular}

*MacKinnon (1996) one-sided p-values.

Augmented Dickey-Fuller Test Equation

Dependent Variable: D(LOG(GEXP))

Method: Least Squares

Date: 12/26/15 Time: 18:27

Sample (adjusted): 19822014

Included observations: 33 after adjustments 


\begin{tabular}{ccccc}
\hline \hline Variable & Coefficient & Std. Error & t-Statistic & Prob. \\
\hline \hline LOG(GEXP(-1)) & -0.124467 & 0.122319 & -1.017561 & 0.3170 \\
C & 0.474498 & 0.245689 & 1.931300 & 0.0629 \\
@ TREND(1981) & 0.024094 & 0.027275 & 0.883362 & 0.3841 \\
\hline \hline R-squared & 0.053139 & Mean dependent var & 0.181653 \\
Adjusted R-squared & -0.009985 & S.D. dependent var & 0.225645 \\
S.E. of regression & 0.226769 & Akaike info criterion & -0.043263 \\
Sum squared resid & 1.542724 & Schwarz criterion & 0.092783 \\
Log likelihood & 3.713838 & Hannan-Quinn criter. & 0.002512 \\
F-statistic & 0.841813 & Durbin-Watson stat & 2.362512 \\
Prob(F-statistic) & 0.440855 & & \\
\hline \hline
\end{tabular}

\section{UNIT ROOT RESULT (@ FIRST DIFFERENCE)}

Null Hypothesis: D(LOG(GDP)) has a unit root

Exogenous: Constant, Linear Trend

Lag Length: 0 (Fixed)

\begin{tabular}{cccc}
\hline \hline & t-Statistic & Prob. $^{*}$ \\
\hline \hline & & & \\
& & & \\
\multicolumn{2}{c}{ Augmented Dickey-Fuller test statistic } & -5.279981 & 0.0008 \\
\hline Test critical values: & $1 \%$ level & -4.273277 & \\
& $5 \%$ level & GH & \\
& $10 \%$ level & -3.212361 & \\
\hline \hline
\end{tabular}

*MacKinnon (1996) one-sided p-values.

Augmented Dickey-Fuller Test Equation

Dependent Variable: D(LOG(GDP),2)

Method: Least Squares

Date: $12 / 26 / 15$ Time: 18:24

Sample (adjusted): 19832014

Included observations: 32 after adjustments

\begin{tabular}{ccccc}
\hline \hline Variable & Coefficient & Std. Error & t-Statistic & Prob. \\
\hline \hline D(LOG(GDP(-1)) & -0.976220 & 0.184891 & -5.279981 & 0.0000 \\
C & 0.219079 & 0.082074 & 2.669278 & 0.0123 \\
@TREND(1981) & -0.000695 & 0.003719 & -0.186868 & 0.8531 \\
\hline \hline R-squared & 0.491511 & Mean dependent var & 0.001173 \\
Adjusted R-squared & 0.456443 & S.D. dependent var & 0.263302 \\
S.E. of regression & 0.194123 & Akaike info criterion & -0.351589 \\
Sum squared resid & 1.092829 & Schwarz criterion & -0.214176 \\
Log likelihood & 8.625426 & Hannan-Quinn criter. & -0.306041 \\
F-statistic & 14.01588 & Durbin-Watson stat & 2.008506 \\
Prob(F-statistic) & 0.000055 & & \\
\hline \hline
\end{tabular}


Null Hypothesis: D(LOG(OREV)) has a unit root

Exogenous: Constant, Linear Trend

Lag Length: 0 (Fixed)

\begin{tabular}{cccc}
\hline \hline & t-Statistic & Prob. $^{*}$ \\
\hline \hline \multicolumn{2}{c}{ Augmented Dickey-Fuller test statistic } & -6.416124 & 0.0000 \\
\hline Test critical values: & 1\% level & -4.273277 & \\
& 5\% level & -3.557759 & \\
& $10 \%$ level & -3.212361 & \\
\hline \hline
\end{tabular}

*MacKinnon (1996) one-sided p-values.

Augmented Dickey-Fuller Test Equation

Dependent Variable: D(LOG(OREV),2)

Method: Least Squares

Date: 12/26/15 Time: 18:26

Sample (adjusted): 19832014

Included observations: 32 after adjustments

\begin{tabular}{ccccc}
\hline \hline Variable & Coefficient & Std. Error & t-Statistic & Prob. \\
\hline \hline D(LOG(OREV(-1)) & -1.158607 & 0.180577 & -6.416124 & 0.0000 \\
C & 0.378844 & 0.156434 & 2.421741 & 0.0219 \\
@ TREND(1981) & -0.007670 & 0.007520 & -1.019984 & 0.3162 \\
\hline \hline R-squared & 0.587652 & Mean dependent var & 0.002794 \\
Adjusted R-squared & 0.559215 & S.D. dependent var & 0.588834 \\
S.E. of regression & 0.390937 & Akaike info criterion & 1.048519 \\
Sum squared resid & 4.432121 & Schwarz criterion & 1.185932 \\
Log likelihood & -13.77631 & Hannan-Quinn criter. & 1.094068 \\
F-statistic & 20.66450 & Durbin-Watson stat & 2.101900 \\
Prob(F-statistic) & 0.000003 & & \\
\hline \hline
\end{tabular}

Null Hypothesis: D(LOG(GEXP)) has a unit root

Exogenous: Constant, Linear Trend

Lag Length: 0 (Fixed)

\begin{tabular}{cccc}
\hline \hline & t-Statistic & Prob.* $^{*}$ \\
\hline \hline & 1\% level & -8.414963 & 0.0000 \\
\hline Test critical values: & 5\% level & -4.273277 & \\
& 10\% level & -3.557759 & \\
& -3.212361 & \\
\hline \hline
\end{tabular}

*MacKinnon (1996) one-sided p-values. 
Augmented Dickey-Fuller Test Equation

Dependent Variable: D(LOG(GEXP),2)

Method: Least Squares

Date: $12 / 26 / 15$ Time: 18:28

Sample (adjusted): 19832014

Included observations: 32 after adjustments

\begin{tabular}{ccccc}
\hline \hline Variable & Coefficient & Std. Error & t-Statistic & Prob. \\
\hline \hline D(LOG(GEXP(-1))) & -1.381155 & 0.164131 & -8.414963 & 0.0000 \\
C & 0.378680 & 0.085022 & 4.453897 & 0.0001 \\
@ TREND(1981) & -0.006468 & 0.003890 & -1.662710 & 0.1071 \\
\hline \hline R-squared & 0.712471 & Mean dependent var & 0.001375 \\
Adjusted R-squared & 0.692641 & S.D. dependent var & 0.365439 \\
S.E. of regression & 0.202599 & Akaike info criterion & -0.266114 \\
Sum squared resid & 1.190346 & Schwarz criterion & -0.128702 \\
Log likelihood & 7.257831 & Hannan-Quinn criter. & -0.220566 \\
F-statistic & 35.92964 & Durbin-Watson stat & 1.928080 \\
Prob(F-statistic) & 0.000000 & & \\
\hline \hline
\end{tabular}

\section{COINTEGRATION RESULT}

Date: 12/26/15 Time: 18:29

Sample (adjusted): 19832014

Included observations: 32 after adjustments

Trend assumption: Linear deterministic trend

Series: GDP OREV GEXP

Lags interval (in first differences): 1 to 1

Unrestricted Cointegration Rank Test (Trace)

\begin{tabular}{ccccc}
\hline \hline $\begin{array}{c}\text { Hypothesized } \\
\text { No. of CE(s) }\end{array}$ & Eigenvalue & $\begin{array}{c}\text { Trace } \\
\text { Statistic }\end{array}$ & $\begin{array}{c}0.05 \\
\text { Critical Value }\end{array}$ & Prob. $^{* *}$ \\
\hline \hline None $*$ & 0.867230 & 101.9105 & 29.79707 & 0.0000 \\
At most $1 *$ & 0.551708 & 37.29816 & 15.49471 & 0.0000 \\
At most $2 *$ & 0.304592 & 11.62422 & 3.841466 & 0.0007 \\
\hline \hline
\end{tabular}

Trace test indicates 3 cointegrating eqn(s) at the 0.05 level

* denotes rejection of the hypothesis at the 0.05 level

**MacKinnon-Haug-Michelis (1999) p-values

Unrestricted Cointegration Rank Test (Maximum Eigenvalue)

\begin{tabular}{lcccc}
\hline \hline Hypothesized & & Max-Eigen & 0.05 & \\
No. of CE(s) & Eigenvalue & Statistic & Critical Value & Prob.** \\
\hline \hline
\end{tabular}




\begin{tabular}{cllll} 
None $*$ & 0.867230 & 64.61234 & 21.13162 & 0.0000 \\
At most $1 *$ & 0.551708 & 25.67394 & 14.26460 & 0.0005 \\
At most $2 *$ & 0.304592 & 11.62422 & 3.841466 & 0.0007 \\
\hline
\end{tabular}

Max-eigenvalue test indicates 3 cointegrating eqn(s) at the 0.05 level * denotes rejection of the hypothesis at the 0.05 level **MacKinnon-Haug-Michelis (1999) p-values

Unrestricted Cointegrating Coefficients (normalized by $b^{\prime} * S 11 * b=I$ ):

\begin{tabular}{ccc}
\hline \hline GDP & OREV & GEXP \\
-0.000152 & $6.36 \mathrm{E}-06$ & 0.002729 \\
$-6.51 \mathrm{E}-05$ & 0.001213 & -0.002014 \\
0.000108 & 0.001399 & -0.003611 \\
\hline \hline
\end{tabular}

Unrestricted Adjustment Coefficients (alpha):

\begin{tabular}{|c|c|c|c|}
\hline $\begin{array}{c}\mathrm{D}(\mathrm{GDP}) \\
\mathrm{D}(\text { OREV }) \\
\mathrm{D}(\text { GEXP) }\end{array}$ & $\begin{array}{r}2986.456 \\
-41.23235 \\
186.2364\end{array}$ & $\begin{array}{r}-1480.459 \\
253.8571 \\
125.4527\end{array}$ & $\begin{array}{l}-750.7420 \\
-492.6699 \\
-4.094033\end{array}$ \\
\hline \multicolumn{2}{|c|}{1 Cointegrating Equation(s): } & Log likelihood & -764.9062 \\
\hline \multicolumn{4}{|c|}{ Normalized cointegrating coefficients (standard error in parentheses) } \\
\hline GDP & OREV & GEXP & \\
\hline 1.000000 & $\begin{array}{r}-0.041849 \\
(0.89952)\end{array}$ & $\begin{array}{r}-17.95796 \\
(1.77837)\end{array}$ & \\
\hline \multicolumn{4}{|c|}{ Adjustment coefficients (standard error in parentheses) } \\
\hline $\mathrm{D}(\mathrm{GDP})$ & $\begin{array}{r}-0.453812 \\
(0.07841)\end{array}$ & & \\
\hline $\mathrm{D}(\mathrm{OREV})$ & $\begin{array}{l}0.006266 \\
(0.02796)\end{array}$ & & \\
\hline $\mathrm{D}(\mathrm{GEXP})$ & $\begin{array}{r}-0.028300 \\
(0.00538)\end{array}$ & & \\
\hline
\end{tabular}

2 Cointegrating Equation(s): $\quad$ Log likelihood $\quad-752.0692$

\begin{tabular}{ccc}
\hline \hline \multicolumn{3}{c}{ Normalized cointegrating coefficients (standard error in parentheses) } \\
GDP & OREV & GEXP \\
1.000000 & 0.000000 & -18.06803 \\
& & $(0.51579)$ \\
0.000000 & 1.000000 & -2.630143 \\
& & $(0.15143)$ \\
\multicolumn{3}{c}{ Adjustment coefficients (standard error in parentheses) } \\
D(GDP) & -0.357503 & -1.776471 \\
& $(0.07111)$ & $(0.52173)$
\end{tabular}




$\begin{array}{lrr}\mathrm{D}(\text { OREV }) & -0.010249 & 0.307609 \\ & (0.02932) & (0.21512) \\ \mathrm{D}(\text { GEXP }) & -0.036461 & 0.153330 \\ & (0.00429) & (0.03145)\end{array}$

\section{VECTOR ERROR CORRECTION}

Vector Error Correction Estimates

Date: 12/26/15 Time: 18:32

Sample (adjusted): 19842014

Included observations: 31 after adjustments

Standard errors in ( ) \& t-statistics in [ ]

\begin{tabular}{|c|c|c|c|}
\hline Cointegrating Eq: & CointEq1 & & \\
\hline GDP(-1) & 1.000000 & & \\
\hline OREV(-1) & $\begin{array}{r}1.718481 \\
(0.93153) \\
{[1.84479]}\end{array}$ & & \\
\hline $\operatorname{GEXP}(-1)$ & $\begin{array}{r}-16.69059 \\
(1.99773) \\
{[-8.35477]}\end{array}$ & & \\
\hline $\mathrm{C}$ & 3734.527 & & \\
\hline Error Correction: & $\mathrm{D}(\mathrm{GDP})$ & $\mathrm{D}(\mathrm{OREV})$ & $\mathrm{D}(\mathrm{GEXP})$ \\
\hline CointEq1 & $\begin{array}{r}-0.519923 \\
(0.13632) \\
{[-3.81406]}\end{array}$ & $\begin{array}{r}-0.223663 \\
(0.05130) \\
{[-4.35969]}\end{array}$ & $\begin{array}{r}-0.031344 \\
(0.01203) \\
{[-2.60457]}\end{array}$ \\
\hline $\mathrm{D}(\mathrm{GDP}(-1))$ & $\begin{array}{r}0.585738 \\
(0.12777) \\
{[4.58415]}\end{array}$ & $\begin{array}{r}0.232940 \\
(0.04809) \\
{[4.84409]}\end{array}$ & $\begin{array}{r}0.039860 \\
(0.01128) \\
{[3.53376]}\end{array}$ \\
\hline $\mathrm{D}(\mathrm{GDP}(-2))$ & $\begin{array}{r}0.548105 \\
(0.14849) \\
{[3.69112]}\end{array}$ & $\begin{array}{c}0.133205 \\
(0.05588) \\
{[2.38356]}\end{array}$ & $\begin{array}{r}-0.016382 \\
(0.01311) \\
{[-1.24968]}\end{array}$ \\
\hline $\mathrm{D}(\mathrm{OREV}(-1))$ & $\begin{array}{r}-3.131149 \\
(0.43105) \\
{[-7.26396]}\end{array}$ & $\begin{array}{r}-0.183655 \\
(0.16223) \\
{[-1.13210]}\end{array}$ & $\begin{array}{r}0.019490 \\
(0.03805) \\
{[0.51217]}\end{array}$ \\
\hline $\mathrm{D}(\mathrm{OREV}(-2))$ & $\begin{array}{r}0.417070 \\
(0.62768) \\
{[0.66446]}\end{array}$ & $\begin{array}{r}-0.061232 \\
(0.23623) \\
{[-0.25921]}\end{array}$ & $\begin{array}{r}0.139950 \\
(0.05541) \\
{[2.52565]}\end{array}$ \\
\hline $\mathrm{D}(\operatorname{GEXP}(-1))$ & -5.324755 & -5.189984 & -0.619377 \\
\hline
\end{tabular}




\begin{tabular}{crrr} 
& $(3.73886)$ & $(1.40711)$ & $(0.33007)$ \\
& {$[-1.42417]$} & {$[-3.68840]$} & {$[-1.87653]$} \\
D(GEXP(-2)) & 0.178249 & -4.921231 & -0.014240 \\
& $(3.69487)$ & $(1.39055)$ & $(0.32618)$ \\
& {$[0.04824]$} & {$[-3.53905]$} & {$[-0.04366]$} \\
C & 1532.814 & 962.0293 & 147.3366 \\
& $(707.623)$ & $(266.312)$ & $(62.4687)$ \\
& {$[2.16615]$} & {$[3.61242]$} & {$[2.35857]$} \\
\hline \hline R-squared & 0.894600 & 0.626872 & 0.669268 \\
Adj. R-squared & 0.862521 & 0.513311 & 0.568610 \\
Sum sq. resids & $1.04 \mathrm{E}+08$ & 14785572 & 813546.3 \\
S.E. equation & 2130.426 & 801.7799 & 188.0733 \\
F-statistic & 27.88797 & 5.520138 & 6.648960 \\
Log likelihood & -276.9469 & -246.6523 & -201.7022 \\
Akaike AIC & 18.38367 & 16.42918 & 13.52918 \\
Schwarz SC & 18.75373 & 16.79924 & 13.89924 \\
Mean dependent & 2868.825 & 218.9184 & 147.2948 \\
S.D. dependent & 5745.779 & 1149.289 & 286.3469 \\
\hline Determinant resid covariance (dof adj.) & $5.90 \mathrm{E}+16$ & \\
Determinant resid covariance & $2.41 \mathrm{E}+16$ & \\
Log likelihood & & -716.6430 & \\
Akaike information criterion & 47.97697 & \\
Schwarz criterion & & 49.22592 & \\
\hline \hline
\end{tabular}

System: UNTITLED

Estimation Method: Least Squares

Date: 12/26/15 Time: 18:33

Sample: 19842014

Included observations: 31

Total system (balanced) observations 93

\begin{tabular}{ccccc}
\hline \hline & Coefficient & Std. Error & t-Statistic & Prob. \\
\hline \hline $\mathrm{C}(1)$ & -0.519923 & 0.136317 & -3.814062 & 0.0003 \\
$\mathrm{C}(2)$ & 0.585738 & 0.127774 & 4.584153 & 0.0000 \\
$\mathrm{C}(3)$ & 0.548105 & 0.148493 & 3.691119 & 0.0004 \\
$\mathrm{C}(4)$ & -3.131149 & 0.431053 & -7.263961 & 0.0000 \\
$\mathrm{C}(5)$ & 0.417070 & 0.627682 & 0.664461 & 0.5086 \\
$\mathrm{C}(6)$ & -5.324755 & 3.738857 & -1.424167 & 0.1589 \\
$\mathrm{C}(7)$ & 0.178249 & 3.694866 & 0.048242 & 0.9617 \\
$\mathrm{C}(8)$ & 1532.814 & 707.6226 & 2.166146 & 0.0338 \\
$\mathrm{C}(9)$ & -0.223663 & 0.051303 & -4.359689 & 0.0000 \\
$\mathrm{C}(10)$ & 0.232940 & 0.048088 & 4.844086 & 0.0000 \\
$\mathrm{C}(11)$ & 0.133205 & 0.055885 & 2.383557 & 0.0199 \\
$\mathrm{C}(12)$ & -0.183655 & 0.162225 & -1.132096 & 0.2615
\end{tabular}




$\begin{array}{lcccc}C(13) & -0.061232 & 0.236226 & -0.259208 & 0.7962 \\ C(14) & -5.189984 & 1.407108 & -3.688404 & 0.0004 \\ C(15) & -4.921231 & 1.390552 & -3.539047 & 0.0007 \\ C(16) & 962.0293 & 266.3118 & 3.612417 & 0.0006 \\ C(17) & -0.031344 & 0.012034 & -2.604571 & 0.0113 \\ C(18) & 0.039860 & 0.011280 & 3.533760 & 0.0007 \\ C(19) & -0.016382 & 0.013109 & -1.249680 & 0.2156 \\ C(20) & 0.019490 & 0.038053 & 0.512168 & 0.6102 \\ C(21) & 0.139950 & 0.055412 & 2.525646 & 0.0138 \\ C(22) & -0.619377 & 0.330065 & -1.876530 & 0.0648 \\ C(23) & -0.014240 & 0.326182 & -0.043657 & 0.9653 \\ C(24) & 147.3366 & 62.46870 & 2.358566 & 0.0212\end{array}$

\begin{tabular}{|c|c|c|c|}
\hline \multicolumn{2}{|c|}{ Determinant residual covariance } & \multicolumn{2}{|c|}{$41 \mathrm{E}+16$} \\
\hline \multicolumn{4}{|c|}{$\begin{array}{l}\text { Equation: } \mathrm{D}(\mathrm{GDP})=\mathrm{C}(1) *(\mathrm{GDP}(-1)+1.71848109687 * \mathrm{OREV}(-1)- \\
16.6905923487 * \mathrm{GEXP}(-1)+3734.52650095)+\mathrm{C}(2) * \mathrm{D}(\mathrm{GDP}(-1))+ \\
\mathrm{C}(3) * \mathrm{D}(\mathrm{GDP}(-2))+\mathrm{C}(4) * \mathrm{D}(\mathrm{OREV}(-1))+\mathrm{C}(5) * \mathrm{D}(\mathrm{OREV}(-2))+\mathrm{C}(6) \\
* \mathrm{D}(\mathrm{GEXP}(-1))+\mathrm{C}(7) * \mathrm{D}(\mathrm{GEXP}(-2))+\mathrm{C}(8) \\
\text { Observations: } 31\end{array}$} \\
\hline R-squared & 0.894600 & Mean dependent var & 2868.824 \\
\hline Adjusted R-squared & 0.862521 & S.D. dependent var & 5745.779 \\
\hline S.E. of regression & 2130.426 & Sum squared resid & $1.04 \mathrm{E}+08$ \\
\hline Durbin-Watson stat & 1.455202 & & \\
\hline \multicolumn{4}{|c|}{$\begin{array}{c}\text { Equation: } \mathrm{D}(\mathrm{OREV})=\mathrm{C}(9) *(\mathrm{GDP}(-1)+1.71848109687 * \mathrm{OREV}(-1)- \\
\text { 16.6905923487*GEXP(-1)+ 3734.52650095) + C(10)*D(GDP }(-1))+ \\
\mathrm{C}(11) * \mathrm{D}(\mathrm{GDP}(-2))+\mathrm{C}(12) * \mathrm{D}(\mathrm{OREV}(-1))+\mathrm{C}(13) * \mathrm{D}(\mathrm{OREV}(-2))+\mathrm{C}(14) \\
* \mathrm{D}(\mathrm{GEXP}(-1))+\mathrm{C}(15) * \mathrm{D}(\mathrm{GEXP}(-2))+\mathrm{C}(16) \\
\text { Observations: } 31\end{array}$} \\
\hline R-squared & 0.626872 & Mean dependent var & 218.9184 \\
\hline Adjusted R-squared & 0.513311 & S.D. dependent var & 1149.289 \\
\hline S.E. of regression & 801.7798 & Sum squared resid & 14785572 \\
\hline Durbin-Watson stat & 2.265256 & & \\
\hline \multicolumn{4}{|c|}{$\begin{array}{c}\text { Equation: } \mathrm{D}(\mathrm{GEXP})=\mathrm{C}(17) *(\mathrm{GDP}(-1)+1.71848109687 * \mathrm{OREV}(-1)- \\
\text { 16.6905923487*GEXP(-1) + 3734.52650095 ) + C(18)*D(GDP }(-1))+ \\
\mathrm{C}(19) * \mathrm{D}(\mathrm{GDP}(-2))+\mathrm{C}(20) * \mathrm{D}(\mathrm{OREV}(-1))+\mathrm{C}(21) * \mathrm{D}(\mathrm{OREV}(-2))+\mathrm{C}(22) \\
* \mathrm{D}(\mathrm{GEXP}(-1))+\mathrm{C}(23) * \mathrm{D}(\mathrm{GEXP}(-2))+\mathrm{C}(24) \\
\text { Observations: } 31\end{array}$} \\
\hline R-squared & 0.669268 & Mean dependent var & 147.2948 \\
\hline Adjusted R-squared & 0.568610 & S.D. dependent var & 286.3469 \\
\hline S.E. of regression & 188.0733 & Sum squared resid & 813546.4 \\
\hline Durbin-Watson stat & 2.059213 & & \\
\hline
\end{tabular}

